\title{
Production of xanthan gum from soybean biodiesel: a preliminary study
}

\author{
Davi da S Ferreira ${ }^{*}$, Larissa A de Souza Costa ${ }^{2}$, Márcio Inomata Campos ${ }^{2}$, Mozart D Bispo ${ }^{3}$, Laiza C Krause ${ }^{3}$, \\ Maria Lucila Hernández Macedo ${ }^{3}$, Jorge A Lopez ${ }^{3}$ \\ From 5th Congress of the Brazilian Biotechnology Society (SBBIOTEC) \\ Florianópolis, Brazil. 10-14 November 2013
}

\section{Background}

Xanthan gum, a commercial microbial polysaccharide, has many industrial applications, including the tertiary recovery of oil, due to its unique rheological behavior $(e$. $g$. high viscosity at low concentrations, pseudoplasticity, solubility, stability over a wide range of $\mathrm{pH}$ values and temperatures, compatibility with many salts) [1]. Its production employs glucose or sucrose, which raises the price of xanthan production. One way to reduce the cost is to use cheaper alternative substrates, like residues [2]. Biodiesel is included in this context because its chemical composition is susceptible to oxidation, which decreases its capacity as a fuel, resulting in the possibility of organic residue accumulation [3]. Thus, biodiesel conversion into xanthan gum by a fermentation process is one alternative for reducing costs, since the substrate is a critical aspect in its commercial production, and also for minimizing possible environmental impacts. Accordingly, the goal this study was to evaluate the effect of soybean biodiesel as an alternative substrate for non-food grade xanthan gum biosynthesis.

\section{Methods}

Experiments were carried out in a medium containing 2\% soybean biodiesel as a carbon source, supplemented with $0.01 \%$ urea and $0.1 \% \mathrm{KH}_{2} \mathrm{PO}_{4}$, using sucrose as control carbon source under the same operational conditions. In order to obtain the polysaccharide, Xanthomonas campestris pv. campestris 629 was inoculated in these culture media and incubated at $28^{\circ} \mathrm{C}, 200 \mathrm{~min}^{-1}$ for $96 \mathrm{~h}$. All assays were performed in triplicate. The recovered biopolymer was dried for analysis. The apparent viscosities of the gum solutions from biodiesel and sucrose were

${ }^{1}$ Curso de Farmácia, Universidade Tiradentes, Aracaju, SE, Brazil

Full list of author information is available at the end of the article measured in a concentric cylinder rheometer coupled to a wash bath for temperature control $(25,45,65$ and $85^{\circ} \mathrm{C}$ ), with at a shear rate of 25 to $1000 \mathrm{~s}^{-1}$. Rheological data were measured according to the Ostwald-de-Waele model $\left(\mu=K(\gamma)^{n-1}\right)$, using a regression analysis to ascertain the apparent viscosity $\left(K, n, R^{2}\right)$ [4]. The xanthan FTIR analysis was obtained in the range $4.000-400 \mathrm{~cm}^{-1}$ in $\mathrm{KBr}$ pellets at room temperature.

\section{Results and conclusions}

The results showed that soybean biodiesel as an alternative carbon source supported xanthan production with a yield of $12.89 \pm 0.61 \mathrm{~g} \times \mathrm{L}^{-1}$. This biopolymer exhibited a consistency index $(K)$ of $937.3 \pm 0.2 \mathrm{mPa} . \mathrm{s}$ and flow rate $(n)$ of $0.61 \pm 0.01$, and $R^{2}=0.99$. These values were similar to those determined for sucrose, the usual carbon source employed for xanthan gum production. The apparent viscosity of xanthan from biodiesel presented a similar profile when compared to gum from sucrose. Regarding the FTIR analysis, both gums showed a similar spectral behavior, probably owing to the polymer structural proximities. The results indicated that biodiesel is a potential and promising option as an alternative substrate for the production of non-food grade xanthan, due to the observed rheological properties indicated through to $K$ and $n$ values [1,5]. However, fermentation conditions need to be optimized in order to improve yield in this polymer production.

\section{Acknowledgements \\ CNPq and FAPITEC for financial support and fellowship. \\ Authors' details \\ ${ }^{1}$ Curso de Farmácia, Universidade Tiradentes, Aracaju, SE, Brazil. \\ ${ }^{2}$ Departamento de Engenharia Química, Escola Politécnica, Universidade Federal da Bahia, Salvador, BA, Brazil. Programa de Pós-Graduação em}


Published: 1 October 2014

\section{References}

1. Palaniraj A, Jayaraman V: Production, recovery and applications of xanthan gum by Xanthomonas campestris. J Food Eng 2011, 106:1-12.

2. Kreyenschulte $D$, Krull $R$, Margaritis A: Recent advances in microbial biopolymer production and purification. Crit Rev Biotechnol in press; 2013.

3. Sørensen G, Pedersen DV, Nørgaard AK, Sørensen KB, Nygaard SD: Microbial growth studies in biodiesel blends. Bioresource Technol 2011 102:5259-5264.

4. Williams PR: Rheometry for non-Newtonian fluids. In In Non-Newtonian flow in the process industries Fundamentals and engineering applications Chhabra RP, Richardson JF. Great Britain: Butterworth Heinemann; 1999, 37-72.

5. Casas JA, Santos VE, García-Ochoa F: Xanthan gum production under several operational conditions: molecular structure and rheological properties. Enzyme Microb Tech 2000, 26:282-291.

doi:10.1186/1753-6561-8-S4-P174

Cite this article as: Ferreira et al:: Production of xanthan gum from soybean biodiesel: a preliminary study. BMC Proceedings 2014 8(Suppl 4): P174.

\section{Submit your next manuscript to BioMed Central} and take full advantage of:

- Convenient online submission

- Thorough peer review

- No space constraints or color figure charges

- Immediate publication on acceptance

- Inclusion in PubMed, CAS, Scopus and Google Scholar

- Research which is freely available for redistribution

Submit your manuscript at www.biomedcentral.com/submit 